\title{
Probability Scale of Vessel Risks on a Shipping Company
}

\author{
Shahro Muttaqin ${ }^{1}$ and Christiono Utomo ${ }^{2}$ \\ ${ }^{1}$ Department of Management Technology, Institut Teknologi Sepuluh Nopember, Surabaya \\ ${ }^{2}$ Department of Civil Engineering, Institut Teknologi Sepuluh Nopember, Surabaya \\ e-mail:shahro.muttaqin@gmail.com
}

\begin{abstract}
Indonesia as one of the biggest maritime country in the world, makes sea transportation an important mode of transportation in Indonesia. A sea transportation is a vessel owned by a shipowner or shipping company. The owners have responsibilities in the operation of vessels and its cargos. Shipowners barely understand the risks that follow them on the sailing such as PT $X$. This private company is one of shipping companies that has sailing route from Surabaya to west Indonesia. High level of vessel accidents in west Indonesia makes the Java Sea a risk-prone area by NTSC. This paper reports interview with $P T X$ and validated by a marine expert to analyze risk factors in vessels. The method conducted was a survey to collect mean index data for probability risk analysis. It is identified that the highest probability of risk is caused by the lack of experiences from the crews, work accidents on the boat, high fuel cost and others. Hence, this report concludes that this examination of risk probability of ship events to a ship company shows types of risk that have the highest probability in order to be mitigated so that the loss will be able to be reduced.
\end{abstract}

Keywords-Interview, Probability Risks, Shipping Company.

\section{INTRODUCTION}

$\mathrm{B}$ ASED on United Nations Convention on the Law of the Sea (UNCLOS) 1982, Indonesia has sea area 5.9 million $\mathrm{km} 2$, consisting of 3.2 million $\mathrm{km} 2$ of territorial water and 2.7 $\mathrm{km} 2$ exclusive economic zone, this makes Indonesia the biggest archipelago state in the world. Therefore, water transportation plays a significant role for transporting people or goods and takes a lot of benefits for this country, especially in the shipping industry.

Sea transportation needs a harbour for shelter. According to National Transportation Safety Commission (KNKT), Tanjung Perak, located in Surabaya, is the second International Hub harbour after Tanjung Priok, Jakarta.

In Figure 1, it explains the harbours relation in Indonesia, especially for the harbours that function as International Hub. This sort of ports supply a massive number of national and international harbour activities, thus the shipping range is immense as well.

Although sea transportation is very important and is used inter-island some areas in Indonesian sea are dangerous. Based on the study conducted by KNKT (2010), some shipping channels which is shown in Figure 2 have alarming zones or redline. The redline is divided into three levels: level I, the most dangerous area, is in Java Sea, Malaka Strait, Sulawesi Strait and Banda Sea; level II is in Natuna Sea, Sulawesi Sea, Halmahera Sea and Seram Sea; level III is in Lombok Strait.

As it is seen in Figure 2, the route taken from Tanjung Perak Surabaya to the western Indonesia needs to go through
Java Sea which is in redline level I. According to KNKT (2017) data about the performance of transportation safety investigation, the biggest number of accidents happens in Java Sea. There were 10 accidents, including 6 were fire exploded, 2 were sunk, 1 was grounded, and 1 was collided.

From Table 1, it is shown the total number of accidents in Indonesian sea between 2011 and 2019. According to the regulation Article 93 No. 21, 1992 about shipping, shipping court is a pointed institution to do continuation investigation toward accidents in the sea.

The shipping court records 257 accidents in total during 2011-2019, including 74 were sunk, 67 were collided, 66 were grounded, and 39 were fire exploded. These accidents are following some factors, they are human error, force majeure, and some other factors [1]. Besides, the main factor for the accidents depends on the type of the accident, operational condition, and the characters of the ships [2].

According to Agoes, the scope of work for shipping court is immense; it covers the whole Indonesian area; therefore, most of the accidents weren't taken to the shipping court [3]. From this condition, it is assumed that the number of accidents is more than it is written.

This high risk of shipping makes some companies and some ships owners have to take a risk toward their businesses. PT. X, one of the shipping company in Surabaya, for instance. PT. X operates their business in deliverying goods/cargo and shipping agent from Surabaya to Pekanbaru, Morombo, Morowali, Marunda and Pontianak. With this route, PT. X must go through Java Sea, redline level I.

In brief, the contributions of this paper are mainly related to proposing the probability scale of vessel risks to improve safety management by shipping company, especially PT. X. Noteworthy, this probability scale analysis includes: (1) risk identification in which the potential risks of the organization identified; (2) risk analysis in which the risk factor (probability) is analysed; and finally (3) risk evaluation in which those risks needing treatment are determined.

The rest of the paper is organized as follows. The method is used in Section II. The results and discussion of this paper are elaborated in Section III. Finally, Section IV provides concluding remarks and directions for further research.

\section{METHOD}

Risk is a probable event which can harm shipping companies; according to Mulcahy's book, risk happens in positive way or negative way toward companies' project [4]. IMO (2007) defines risk as a combination between frequency and consequence or level of damage emerged. Frequency means the total accident divided by unit of time, while 
The $1^{\text {st }}$ International Conference on Business and Engineering Management (IConBEM)

February $1^{\text {st }} 2020$, Institut Teknologi Sepuluh Nopember, Surabaya, Indonesia

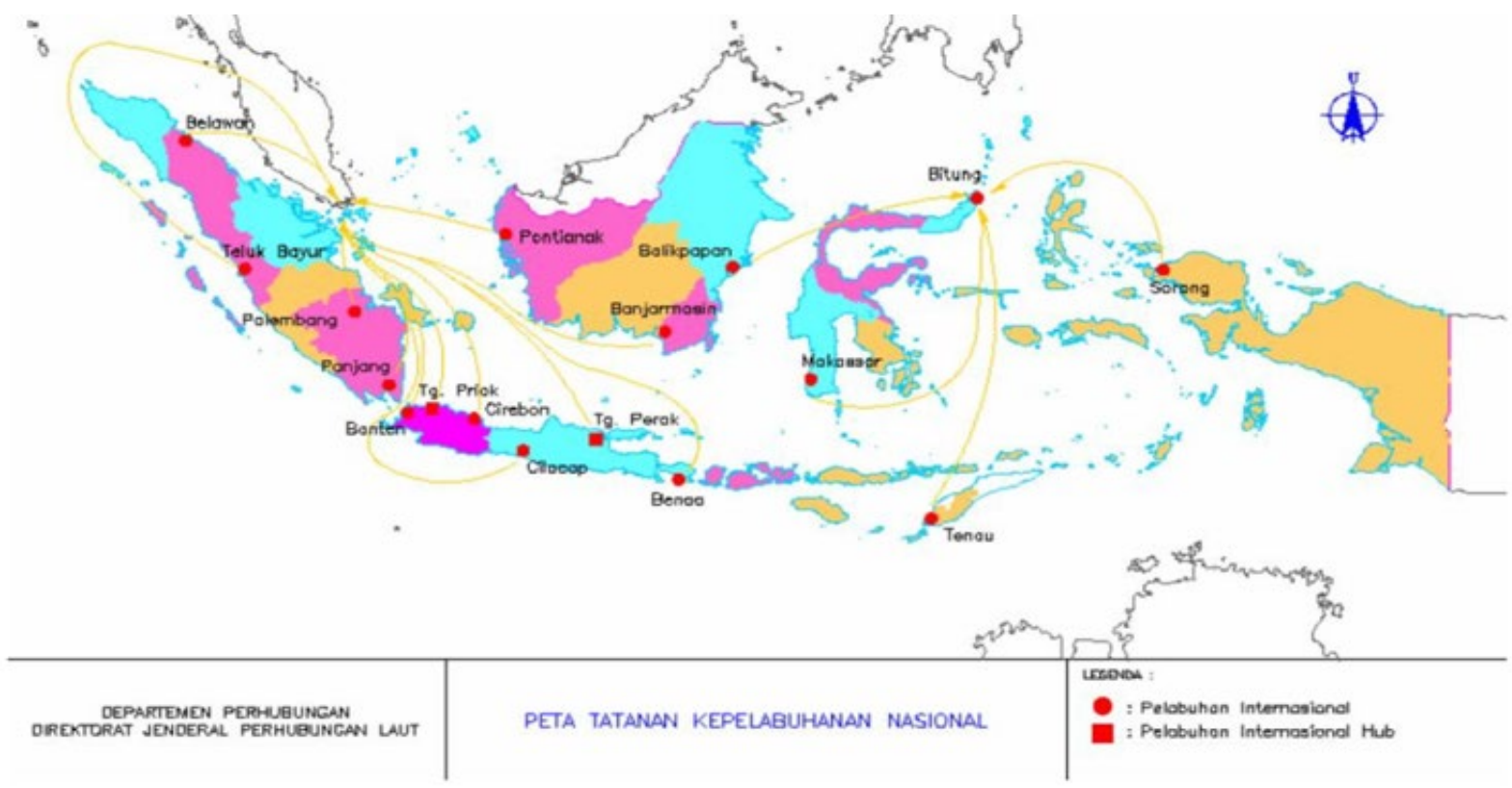

Figure 1. The National Port Systems of Indonesia by KNKT (2010)

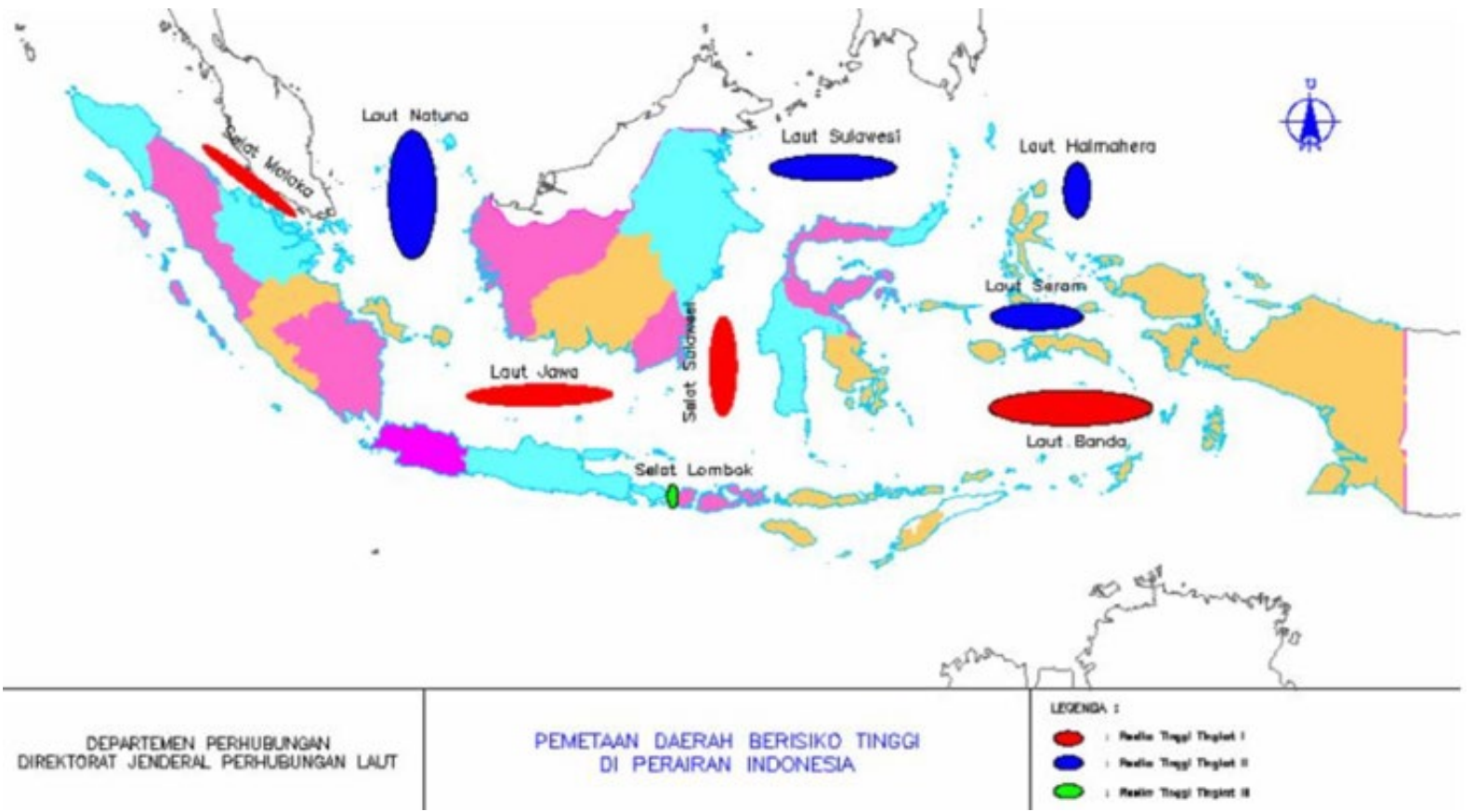

Figure 2. High Risk Areas in Indonesian Waters' by KNKT (2010)

consequence means the effect that appears as a result of the accident. From this definition, the probability of risk and its effect to the business can be identified and measured [5].

This study aims to see the probability of vessel risk on shipping companies, especially PT. X using these following steps:

\section{A. Risk Identification}

One of the risk identification method is Review Historical Records [4]. This method is done by looking at records from past projects because it will save time in risk management and avoid repeating the mistakes of others. Review historical records needs to comprehend the following lists:
1) List of risk
2) List of risk categories
3) Probability and impact of risks

4) Risk response plans

5) Lessons learned

This paper reviews historical records to validate the previous research. Based on Sebayang, about a shipping company, Harbour Tug, there are some risk factors that threaten shipping companies which will be provided in the chapter III [6].

The second method to identify risks is expert interview. This interview with PT. X aims to validate that whether the risks threaten the company. Expert Interview method has some benefits as follows [4]:

1) Obtain an understanding of unfamiliar parts of the projects

2) Uncover new risks that could not be uncovered from other sources 


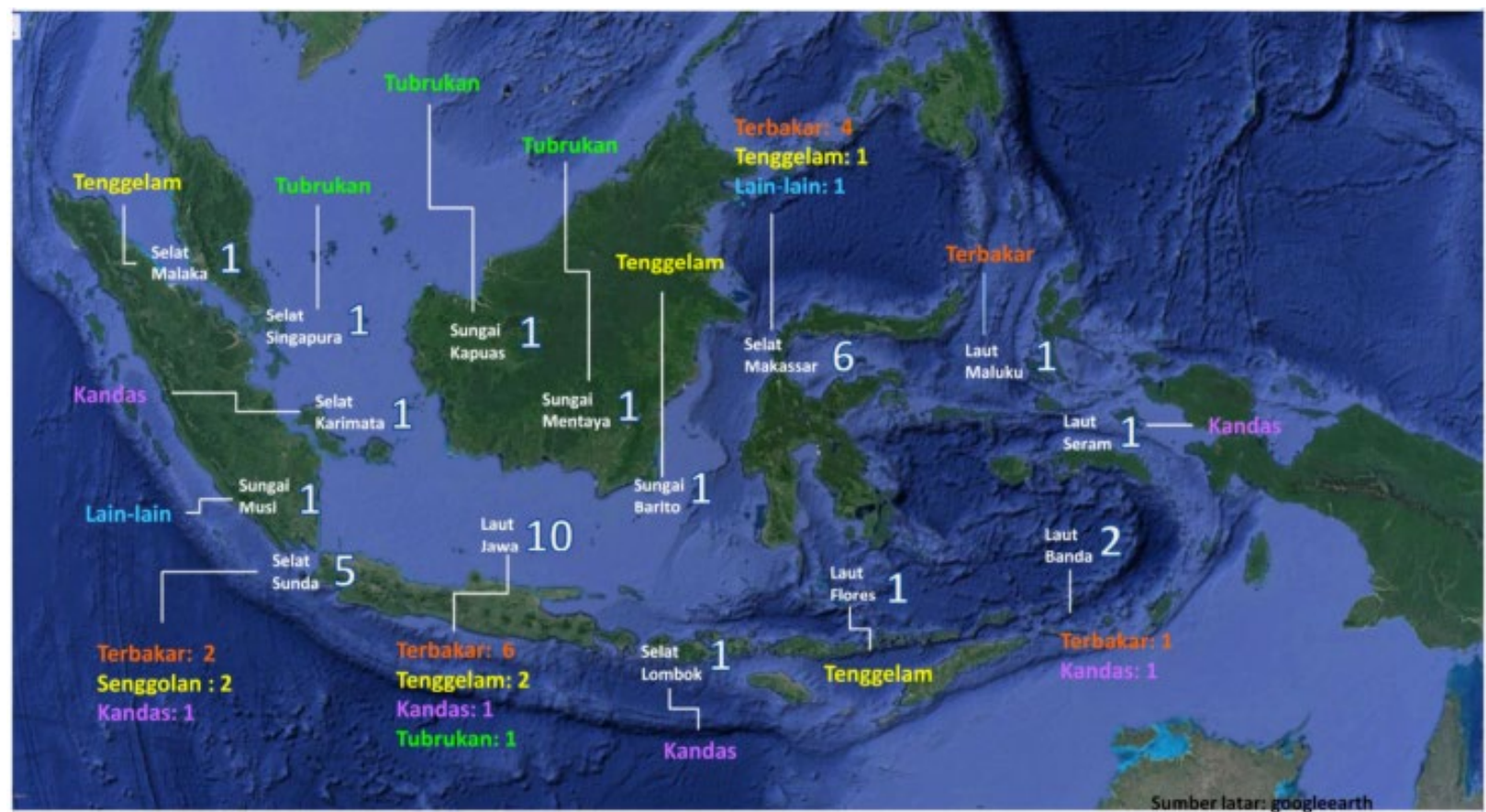

Figure 3. Distribution of Vessel Accidents Investigation in 2017 by KNKT

Table 1.

Statistic Data of Vessel Accidents from 2011-2019 by Shipping Court Indonesia

\begin{tabular}{|c|c|c|c|c|c|c|c|c|c|c|}
\hline & $\stackrel{\widetilde{\theta}}{\Xi}$ & $\stackrel{\stackrel{N}{N}}{\stackrel{N}{0}}$ & $\underset{\omega}{\stackrel{\omega}{\omega}}$ & $\underset{\oplus}{\stackrel{\theta}{\theta}}$ & 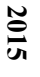 & $\frac{\mathfrak{a}}{a}$ & $\underset{\mathfrak{v}}{\stackrel{N}{\Xi}}$ & $\underset{\infty}{\stackrel{N}{\sigma}}$ & $\stackrel{\sim}{\stackrel{\sigma}{\sigma}}$ & Total \\
\hline 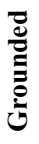 & 3 & 2 & 14 & 12 & 3 & 10 & 10 & 9 & 3 & 66 \\
\hline 光 & 3 & 17 & 4 & 10 & 8 & 14 & 6 & 11 & 1 & 74 \\
\hline 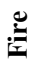 & 4 & 6 & 5 & 5 & 3 & 3 & 7 & 6 & 0 & 39 \\
\hline 六 & 9 & 6 & 8 & 19 & 4 & 6 & 5 & 7 & 3 & 67 \\
\hline 节 & 2 & 3 & 2 & 3 & 1 & 0 & 0 & 0 & 0 & 11 \\
\hline 푱 & 21 & 34 & 33 & 49 & 19 & 33 & 28 & 33 & 7 & 257 \\
\hline
\end{tabular}

3) Gain information about probability, fallback plans for using in qualitative risk analyzing and response planning This method is done with some company's official, such as Director and Operational Manager. Besides, the result of the interview should be validated by a marine expert, an adjuster or Manager of Marine Division of PT. Y who evaluates company's loss.

\section{B. Risk Assessment}

Risk assessment is a developing area to improve business operational and risk exposure in order to get the result [7]. Risk assessment is part of risk management which provides structured process; this is to identify how the result affects the
Table 2.

Risk Categories in Harbour Tug's Shipping Company (zefanya, 2019)

\begin{tabular}{cc}
\hline No & Risk Categories \\
\hline 1 & Work accident \\
2 & Lack of ship crew \\
3 & Lack of ship crew's skill \\
4 & Equipment stealing \\
5 & The change of customers' need \\
6 & The lateness of goods/cargo delivery \\
7 & Ship collision \\
8 & Fire explosion \\
9 & Engine failure \\
10 & The lateness of ship reparation \\
11 & The lateness of spare parts to come \\
12 & The increase of fuel price \\
\hline \hline
\end{tabular}

goal and to analyse the risk in consequence and probability before deciding whether maintenance is needed. The aim of this method is to assess a risk whether it is safe and is accepted or not.

Arfian stated, that this process is to identify all the bad possibilities which can harm human's health, environment, process of production and equipment caused by human and technology activities [8]. This method starts with assigning the frequency of the damage or the probability of the damage occurence or how often the event happens, because risk is the combination between probability and consequence.

\section{Risk Evaluation}

Based on Rahman et al., the aim of risk evaluation is to support the decision by comparing the result of analysing risk to the risk criteria [1].

Indeed, this process needs to determine the financial obligation, government, and society. The organisation is supposed to realise the threats and susceptibility of any resources, especially for people who are in high priority or in significant time replacement.

Furthermore, the organisation must select the right method to identify, analyse, and evaluate threatening risks. ISO 
The $1^{\text {st }}$ International Conference on Business and Engineering Management (IConBEM)

February $1^{\text {st }} 2020$, Institut Teknologi Sepuluh Nopember, Surabaya, Indonesia

Table 3.

Risk Factor Result After The Interview with PT. X

\begin{tabular}{cc}
\hline No & Risk Categories \\
\hline 1 & Work accident \\
2 & Lack of ship crew's skill \\
3 & Equipment stealing \\
4 & The change of customers' need \\
5 & The lateness of goods/cargo delivery \\
6 & Ship collision \\
7 & Fire explosion \\
8 & Engine failure \\
9 & The lateness of ship reparation \\
10 & The lateness of spare parts arrival \\
11 & The increase of fuel price \\
12 & Grounded ship \\
13 & Sunk ship \\
\hline
\end{tabular}

Table 4.

The Result Of Risk Assessment of PT. X Using Questionnaire

\begin{tabular}{clccc}
\hline \hline No & \multicolumn{1}{c}{ Risk Categories } & A & B & C \\
\hline 1 & Work accident & 7 & 3 & 4 \\
2 & Lack of ship crew's skill & 8 & 2 & 7 \\
3 & Equipment stealing & 5 & 2 & 2 \\
4 & The change of customers' need & 1 & 2 & 2 \\
5 & The lateness of goods/cargo delivery & 4 & 2 & 5 \\
6 & Ship collision & 2 & 5 & 4 \\
7 & Fire explosion & 2 & 5 & 1 \\
8 & Engine failure & 2 & 3 & 1 \\
9 & The lateness of ship reparation & 2 & 3 & 2 \\
10 & The lateness of spare parts arrival & 1 & 3 & 2 \\
11 & The increase of fuel price & 7 & 2 & 5 \\
12 & Grounded ship & 2 & 5 & 6 \\
13 & Sunk ship & 2 & 5 & 2 \\
\hline
\end{tabular}

Note:

$\mathrm{A}=$ Director of PT. X

B = Manager of Operational PT. X

$\mathrm{C}=$ Manager of Marine Division PT. Y

31000 has established principles and standard guidelines of risk management, as follows:

1) Criteria of risks acceptance: the portrayed situation in which the company is willing to accept the risk is fully described;

2) Risk level identification: by using any approaches of risk assessment, the level of risk should be identified;

3) Risk analysis: the concepts below are to value risk assessment:

a. Threats are described as events or activities which can impact the resources, for instance fire, flood, power failure, the decrease number of staff and/or their absences, computer virus, and hardware failure.

b. The vulnerability of resource would be a weakness and could be exploited by the threats, such as failure, susceptible to fire, electricity endurance, staff level, safety, and IT strength.

\section{RESULTS AND DISCUSSION}

Based on the previous research of Sebayang, there are some types of risk which is suitable with the vessel risk on the shipping company [6]. The risk types are shown in Table 2 .
Table 5.

Probability Scale of risk management (Mulcahy, 2010)

\begin{tabular}{|c|c|c|c|c|c|}
\hline \multicolumn{6}{|c|}{ Probability Scales } \\
\hline Option & & & Rating & & \\
\hline 1 & Very Low & Low & Moderate & High & Very High \\
\hline 2 & .05 & 0,1 & 0,2 & 0,4 & 0,8 \\
\hline 3 & 0,1 & 0,3 & 0,5 & 0,7 & 0,9 \\
\hline 4 & 2 & 34 & 5 & 78 & 10 \\
\hline
\end{tabular}

Table 6. Result of risk probability scale assessment on pt. $\mathrm{x}$

\begin{tabular}{clccc}
\hline \hline No & \multicolumn{1}{c}{ Risk Categories } & $\begin{array}{c}\text { Risk } \\
\text { Value }\end{array}$ & $\begin{array}{c}\text { Risk } \\
\text { Rank }\end{array}$ & $\begin{array}{c}\text { Kategori } \\
\text { Risiko }\end{array}$ \\
\hline 1 & Work accident & 5 & 2 & Moderate \\
2 & Lack of ship crew's skill & 6 & 1 & Moderate \\
3 & Equipment stealing & 3 & 7 & Low \\
4 & The change of customers' need & 1 & 13 & Very low \\
5 & The lateness of goods/cargo delivery & 4 & 4 & Low \\
6 & Ship collision & 4 & 5 & Low \\
7 & Fire explosion & 2 & 9 & Very low \\
8 & Engine failure & 2 & 10 & Very low \\
9 & The lateness of ship reparation & 2 & 11 & Very low \\
10 & The lateness of spare parts arrival & 2 & 12 & Very low \\
11 & The increase of fuel price & 5 & 3 & Moderate \\
12 & Grounded ship & 4 & 6 & Low \\
13 & Sunk ship & 3 & 8 & Low \\
\hline \hline
\end{tabular}

Table 7.

The Rank of Risk Probability Scale on PT. X

\begin{tabular}{cl}
\hline \hline No & \multicolumn{1}{c}{ Risk Categories } \\
\hline 1 & Lack of ship crew's skill \\
2 & Work accident \\
3 & The increase of fuel price \\
4 & The lateness of goods/cargo delivery \\
5 & Ship collision \\
6 & Grounded ship \\
7 & Equipment stealing \\
8 & Sunk ship \\
9 & Fire explosion \\
10 & Engine failure \\
11 & The lateness of ship reparation \\
12 & The lateness of spare parts arrival \\
13 & The change of customers' need \\
\hline
\end{tabular}

These 12-type of risk were used to interview the Director and Operational Manager of PT. X and to understand if the risks threaten the company. From the interview, it could be obtained that the lack of ship crew does not affect the company because the company owner has provided the minimum of ship crew number before sailing. This rule has been assigned by Harbourmaster. Based on the Indonesian constitution no. 17, 2008 article 1 verse 56, Harbourmaster is a government official in harbours, legitimated by minister, and has the highest authority to run and supervise the harbour activities, and to ensure the shipping safety.

In the contrary, according to the interview, there are two types of risk which threaten PT. X, grounded ship, and sunk ship. These two types of risk are added to the Table 3.

The interview had produced 13 types of risk and the analysis of risk assessment was started to find the risk rank in ascending order. As soon as the interview had finished, the director and the operational manager of PT. X as well as the manager of marine division, an expert maritime, from PT. Y 
The $1^{\text {st }}$ International Conference on Business and Engineering Management (IConBEM)

February $1^{\text {st }} 2020$, Institut Teknologi Sepuluh Nopember, Surabaya, Indonesia

filled out a questionnaire about risk assessment. The result is shown in the Table 4.

The questionnaire assessment of risk probability in Table 5 was done by using some options. In this research, the option number 4 was chosen because it was well-understood by PT. $\mathrm{X}$ and the expert maritime, a loss evaluator, from PT. Y. They rated for the types of risk with the scale of 1-8, while scale 9 and 10 denote a fact where the accident could almost $100 \%$ occur. As a result, only scale 1-8 was used for indicating a risk, not a fact [4].

After filling the questionnaire, the next step would be determining risk rank and category. This determination is essential since there would be risk handling based on the priority risk rank. Besides, Table 5 also provides risk category: scale 1-2 is indicated as very low, scale 3-4 is low, scale 5-6 is moderate, and scale 7-8 is high.

After getting the data about risk probability level on PT. X, the researcher continued with the risk probability assessment. This was done to see which probability could threaten the company by processing the questionnaire result in Table 4 and divided by index average for each risk type [9].

In Table 6, it is shown the result of risk probability assessment, risk rank, and risk category toward the risk types which threaten PT. X. It provides the risk probability value based on the rank. After processing the data, the result of risk probability value of PT. X is obtained based on the rank in ascending order as it is shown in Table 7.

According to Table 7, the lack of ship crew's skill is the main problem in PT. $\mathrm{X}$ as it is in the first place of the risk categories which has the highest rank. Work accident and the increase of fuel price are placed in the second and third biggest risk probability. Consequently, these three risks are classified as moderate with the probability scale of 5-6.

\section{CONCLUSION}

Risk analysis toward risk management to some companies, especially shipping companies, are important for their business. PT. X has only 10 ships as their asset and this is considered as a small shipping company [10]. Because of this, PT. X will be disturbed even if there is small threat occurs. By realising the level of risk probability, PT. X is expected to anticipate and to minimise the risk probability.

Moreover, these top three risks can endanger the company itself. For instance, if the crew lacks shipping skill, it can enlarge the possibility of accident on the ship. Consequently, the work accident on the ship will be followed by another damage and risk, and of course, this causes expensive cost. Finally, the increase of fuel price is also another risk that can affect the company's business operational. PT. $\mathrm{X}$ is a goods/cargo delivery service company in which the business can be obstructed and possibly get another risk; moreover, they will lose the customer.

To develop and complete the further research, the researchers will add some points as follows:

- Add the result of each risk and categorise them into the correct category, so the company knows which risk should get further handling.

- Use another technique of risk assessment, such as modelling technique for risk probability.

- Continue the research with risk evaluation to each risk, which one needs further handling, such as avoid, mitigate, transfer, and accept.

\section{ACKNOWLEDGEMENTS}

This research was supported by Institut Teknologi Sepuluh Nopember. The authors appreciate the constructive comments made by the anonymous reviewers which helped to improve presentation of the paper.

\section{REFERENCES}

[1] H. Rahman, A. Satria, B. H. Iskandar, and D. A. Soeboer, "Penentuan faktor dominan penyebab kecelakaan kapa Kesyahbandaran Utama Tanjung Priok," ALBACORE J. Penelit Perikan. Laut, vol. 1, no. 3, pp. 277-284, 2018, doi: 10.29244/core.1.3.277-284.

[2] C. Grammenos, The Handbook of Maritime Economics and Business, 2nd ed. London, United Kingdom: Lloyd's List, 2010.

[3] E. R. Agoes, "Laporan Akhir Tim Analisis Evaluasi Peraturan Perundang-undangan tentang Yuridiksi dan Kompetensi Mahkamah Pelayaran,” Jakarta, Indonesia, 2005.

[4] R. Mulcahy, Risk Management: Tricks of the Trade for Project Managers and PMI-RMP Exam Prep Guide, 2nd ed. Minnetonka, Minnesota: RMC Publishing, 2010.

[5] N. M. Sirait and A. Susanty, "Analisis risiko operasional berdasarkan pendekatan Enterprise Risk Management (ERM) pada perusahaan pembuatan kardus di CV Mitra Dunia Pallentindo," Ind. Eng. Online J., vol. 5, no. 4, pp. 1-10, 2016.

[6] I. Z. Sebayang, "Penilaian Risiko Berbasis Business Continuity Management di PT. X pada Perusahaan Pelayaran Harbour Tug," Institut Teknologi Sepuluh Nopember, 2019.

[7] M. Mousavi, I. Ghazi, and B. Omaraee, "Risk assessment in the maritime industry," Eng. Technol. Appl. Sci. Res., vol. 7, no. 1, pp 1377-1381, 2016.

[8] Z. Arfian, "Penilaian Risiko Tubrukan Kapal Akibat Instalasi Anjungan Lepas Pantai di Dekat Alur Pelayaran Barat Surabaya," Institut Teknologi Sepuluh Nopember, 2017.

[9] S. Budiwanto, Metode Statistika untuk Mengolah Data Keolahragaan. Malang: UM Press, 2017.

[10] Y. Y. Zeng, S. Gong, and H.-Q. Ye, "Ship Financing Practices in Hong Kong: What Changes has The Financial Tsunami Wrought?,"Hong Kong Polytechnic University, 2008. 